\title{
The relevance of dipeptides and tripeptides in the bioactivity and taste of dry-cured ham
}

\author{
Marta Gallego, Leticia Mora and Fidel Toldrá* (D)
}

\begin{abstract}
Dry-cured ham has been described as a good source of bioactive peptides and taste-active compounds. Some of them are dipeptides and tripeptides that are released in a large amount from different muscle proteins due to the action of exopeptidases during the dry-cured ham processing. The potential of dipeptides and tripeptides to exert bioactivities and impart taste characteristics to dry-cured ham has been evaluated using the BIOPEP database, since in silico approaches are a time- and cost-effective alternative to empirical approaches. Most of the studied dipeptides and tripeptides showed ACE and DPP inhibitory activities as well as imparted bitter taste. In fact, more than one bioactivity and/or taste could be assigned to a given peptide sequence, and there could be a correlation between both, like ACE inhibitory and bitter EA, El and LG peptides. Furthermore, several dipeptides such as $E K, K P, L A, P L, P P, R G$, and $V E$, among others, were found to be multifunctional (ACE and DPP IV inhibitory) which would be determined by their structure, sequence and amino acid composition. In silico analysis evidences the relevance of dipeptides and tripeptides in the bioactivity and taste of dry-cured hams, but further empirical assays including in vitro and in vivo studies are necessary to confirm such theoretical results. Possible degradation of the small peptides during gastrointestinal digestion and intestinal absorption as well as interactions with the food matrix could reduce their bioavailability and bioaccessibility, and modify their biological activities.
\end{abstract}

Keywords: Small peptides, Biological activity, Sensory, Ham, In silico analysis, Multifunctional peptides

\section{Introduction}

Dry-cured ham is a traditional and high-quality product in many countries of the world, especially in the Mediterranean area. Serrano and Iberian hams from Spain, Parma and San Daniele prosciuttos from Italy, and Bayonne hams from France are some of the most valuable. These types of dry-cured hams differ mainly in the raw material (pig breed, age, and feed), and processing conditions (temperature, $\mathrm{pH}$, water activity, redox potential, curing agents, and length of ripening), which are parameters directly related with the quality, texture and flavour of the final product (Toldrá and Flores 1998; Sforza et al. 2006).

Numerous biochemical reactions occur during the dry-curing process, mainly due to the action of endogenous muscle enzymes on lipids and proteins. Lipids of

\footnotetext{
* Correspondence: ftoldra@iata.csic.es

Instituto de Agroquímica y Tecnología de Alimentos (CSIC), Avenue Agustín Escardino 7, 46980 Valencia, Paterna, Spain
}

muscle and adipose tissue are intensely hydrolysed by lipases generating free fatty acids, which are then transformed to volatile compounds as a result of oxidation (Toldrá and Flores 1998). On the other hand, muscle sarcoplasmic and myofibrillar proteins undergo an intense proteolysis generating high amounts of small peptides and free amino acids. This degradation starts with the action of endopeptidases (cathepsins B, D, H, and $\mathrm{L}$ and calpains) that breakdown muscle proteins into longer polypeptides, resulting in texture changes (Toldrá 1998). Subsequently, these polypeptides are hydrolysed by enzymes exopeptidases (mainly peptidyl peptidases, aminopeptidases and carboxypeptidases) into small peptides and free amino acids as final step of the proteolysis, which contribute to the organoleptic characteristics of the final product (Toldrá et al. 2000). The action of endogenous muscular enzymes is affected by the type of muscle and genetics of raw material as well as the processing conditions including added curing agents and

(c) The Author(s). 2019 Open Access This article is distributed under the terms of the Creative Commons Attribution 4.0 International License (http://creativecommons.org/licenses/by/4.0/), which permits unrestricted use, distribution, and 
time of curing (Rico et al. 1991; Toldrá et al. 1993; Mora et al. 2016).

In addition to sensory characteristics, the peptides naturally generated during the dry-cured ham processing may exert physiological effects in the human body. Bioactive peptides are sequences between 2 and 20 amino acids in length that are inactive within the sequence of the parent protein. However, they become active once released after proteolytic processes such as enzymatic or chemical hydrolysis, processing conditions, microbial fermentation, or gastrointestinal digestion. The properties of the bioactive peptides can be affected by the hydrolytic enzymes, processing conditions, and size of the resulting peptides, which greatly determines their absorption and transport across the intestinal epithelium and bioavailability in target tissues (Udenigwe and Aluko 2012; Lafarga and Hayes 2014). Several bioactive peptides have been identified in dry-cured hams, showing activities such as antihypertensive, antioxidant, and antidiabetic, among others (Escudero et al. 2013a; Escudero et al. 2013b; Zhu et al. 2013; Gallego et al. 2014a; Mora et al. 2015a).

Typical empirical approaches for the study of foodderived bioactive peptides involve several steps such as the release of peptides from the parent proteins, fractionation/purification processes, in vitro bioactivity assays, identification of the peptide sequences, synthesis of peptides, and in vitro and in vivo confirmation of the peptide bioactivity (Sánchez-Rivera et al. 2014). In silico analyses combining bioinformatics tools and databases are useful sources of information on biomolecules, being a time- and cost-effective alternative to empirical approaches. In this sense, BIOPEP (www.uwm.edu.pl/biochemia/index.php/en/biopep) is a widely used database for the study, identification, in silico digestion, and prediction of food-derived proteins and peptides. BIOPEP contains databases of bioactive peptides and sensory peptides and amino acids previously described in bibliography, which enable to gain knowledge about the potential of food proteins as precursors of these compounds and about the relationship between their composition and activity (Minkiewicz et al. 2008; Iwaniak et al. 2016a). Also EROP-Moscow (http://erop.inbi.ras.ru/) is a widely used database that provides information about the bioactivity and taste of peptides as well as their source of origin (Zamyatnin et al. 2006). Other bioactive peptide databases include PeptideDB (http:// www.peptides.be/) and PepBank (http://pepbank.mgh. harvard.edu), whereas BitterDB (http://bitterdb.agri. huji.ac.il/dbbitter.php) and SuperSweet (http://bioinformatics.charite.de/sweet/) contain data about tastants (Iwaniak et al. 2016b).

\section{Generation of dipeptides and tripeptides in dry-cured ham}

The proteolysis occurring throughout the processing of dry-cured hams implies the degradation of polypeptides into small peptides and free amino acids by the action of muscle exopeptidases. Small peptides such as dipeptides and tripeptides can be generated in large amounts during this process and could impart taste to the final product. Moreover, after ingestion, the small-size makes these peptides more easily to resist gastrointestinal digestion and be absorbed intact through the intestinal epithelium, promoting potential biological effects in the organism when bioactive.

Several muscle enzymes participate in the generation of dipeptides and tripeptides during the dry-cured ham processing. Tripeptidyl peptidases (TPP I and TPP II) are involved in the sequential release of $\mathrm{N}$-terminal tripeptides and could keep their activity until the first 6 months of the dry-cured ham processing (Toldrá and Flores 1998). Both enzymes display broad substrate specificity and can generate many types of tripeptides; however, TPP I prefers those with hydrophobic amino acids in the terminal position, while TPP II cannot cleave before or after P residues (Tomkinson 1999). Furthermore, dipeptidyl peptidases (DPP I to IV) are a group of enzymes that release dipeptides from the $\mathrm{N}$-terminal end of polypeptides. Briefly, DPP I preferentially hydrolyses Nterminal peptides with basic residues such as $\mathrm{R}$ in the penultimate position but not those with $\mathrm{P}$ on either site of the peptide bond (Sentandreu and Toldrá 2000). DPP III shares some substrate specificities with DPP II (Sentandreu and Toldrá 1998), whereas DPP II and DPP IV hydrolyse P and A residues in the penultimate position at the $\mathrm{N}$-terminal of peptides (Sentandreu and Toldrá 2001a; Sentandreu and Toldrá 2001b). The activity of the DPP during the processing of dry-cured hams has been studied, evidencing the effect of the salt content, $\mathrm{pH}$ and temperature on these enzymes (Sentandreu and Toldrá 2001c; Zhao et al. 2005). In this regard, DPP I could remain strongly active throughout the processing and could be the key enzyme responsible for the generation of dipeptides during the dry-curing stage, whereas the activities of DPP II, III and IV may be limited depending on the processing conditions (Sentandreu and Toldrá 2001c; Zhao et al. 2005). In addition, aminopeptidases and carboxypeptidases catalyse the hydrolysis of single amino acid residues from the $\mathrm{N}$-terminal and $\mathrm{C}$ terminal end, respectively, of peptides and proteins (Toldrá et al. 2000) Aminopeptidases, except pyroglutamyl aminopeptidase, have shown good stability along the drycured ham processing and may be the main contributors to the generation of free amino acids (Toldrá et al. 2000).

Several dipeptides such as AM, GS, IV, or VE were identified by Edman degradation sequencing in peptide 
fractions obtained by gel filtration chromatography of Spanish dry-cured ham extracts (Sentandreu et al. 2003). Later, the use of mass spectrometry (MS) and peptidomic approaches have allowed a better knowledge of the proteolysis occurring in dry-cured hams by identifying the naturally generated peptides and their proteins of origin as well as evidencing the action of exopeptidases in the loss of dipeptides and tripeptides from the terminal positions of peptides.

Thus, it is well known the intense activity of exopeptidases and their responsibility in the release of dipeptides and tripeptides. However, many times the sequences of these small peptides have been elucidated from the identification of longer peptides, which exposes the action of TPP and DPP enzymes (Mora et al. 2009a; Mora et al. 2010; Gallego et al. 2015), due to the important difficulties in the identification of dipeptides and tripeptides from complex matrices as will be later described. In this regard, Table 1 shows the sequences of several dipeptides and tripeptides generated during the processing of dry-cured ham, such as DL and LA from peptides derived from creatine kinase protein (Mora et al. 2009a), PP and SV from titin-derived peptides (Gallego et al. 2015), or IP and NK from troponin T peptides (Mora et al. 2010). Also tripeptides such as EAQ, NMP, SQG, and SVT were lost from the N-terminal end of peptides derived from LIM domain-binding protein 3 (Gallego et al. 2014b), or DKE and VKT from ubiquitinderived peptides (Mora et al. 2015c). Several dipeptides can be generated due to the degradation of peptides derived from different proteins, for example, VK is derived from glyceraldehyde 3-phosphate dehydrogenase, myosin heavy chain, titin, or ubiquitin peptides (Table 1).

Recently, Zhu et al. (Zhu et al. 2017) used MS techniques for the identification and relative quantification of 10 dipeptides (AH, AR, FE, HP, LE, LK, PL, SE, VE, and $\mathrm{YT}$ ) and 14 tripeptides (AAP, DVK, EEE, EGV, GSF, LHA, LKE, LLP, LPK, PPN, SGL, SGV, VAP, and VPL) generated in dry-cured Jinhua ham. The relative peak areas of dipeptides and tripeptides were 23.59 and $48.28 \%$, respectively, and LPK, SGL, AAP, and VE were the most abundant peptides in the post-ageing stage of dry-curing (Zhu et al. 2017). Additionally, MS/MS analysis with multiple reaction monitoring (MRM) mode was employed for the quantification of several dipeptides and tripeptides during the drying and ripening of hams, showing that the dipeptide PG was formed during the ripening and reached a final concentration of $1.3 \mathrm{mg} / 100 \mathrm{~g}$ dry weight ham (Degnes et al. 2017).

\section{Bioactivity of dipeptides and tripeptides}

Dry-cured hams have been reported as a good source of bioactive peptides that are naturally generated by the intense action of endogenous enzymes during processing. The use of MS techniques has allowed the identification of several of these peptides, most of them with sequences of 5-10 amino acid residues and showing angiotensin I-converting enzyme (ACE) inhibitory, antioxidant, antilisterial and DPP IV inhibitory activities, as reviewed by Gallego, Mora, and Toldrá (Gallego et al. 2018). However, gastrointestinal digestion and intestinal transport of the peptides for reaching their target sites can degrade or modify their structure, and thus the bioactivity will depend on the characteristics of the generated peptide fragments (Udenigwe and Aluko 2012). For that reason, the major interest of studying the bioactivity of dipeptides and tripeptides is because they can be absorbed intact from the intestinal lumen into the blood stream in order to produce biological effects at the tissue level (Miner-Williams et al. 2014).

The sequences of dipeptides and tripeptides released from different proteins in dry-cured hams (Table 1) were searched in the BIOPEP database, and those presenting biological activity selected and shown in Table 2. ACE inhibitory and DPP IV inhibitory activities were the most abundant, and such bioactive dipeptides and tripeptides were majorly derived from the degradation of the myofibrillar proteins titin and myosin light and heavy chains, and from the sarcoplasmic protein creatine kinase. Also several peptides with renin inhibitory, stimulating glucose uptake, antioxidant, and DPP III inhibitory activities were found, while other activities such as antitrombotic, antiamnestic, regulator of stomach mucosal membrane activity, stimulating vasoactive substance release, calmodulin-dependent phosphodiesterase (CaMPDE) inhibition, and activating ubiquitin-mediated proteolysis were only reported in unique dipeptides (Table 2). In agreement with these results, a previous in silico study reported the high potential of pork meat myofibrillar proteins for the generation of bioactive peptides after simulated gastrointestinal digestion, with DPP IV inhibitory peptides being the most frequently observed (Kęska and Stadnik 2016). Also nutritional meat compounds such as tripeptide glutathione ( $\gamma$-glutamylcysteinyl-glycine) and dipeptides carnosine ( $\beta$-alanyl-histidine) and anserine ( $\beta$-alanyl-1-methylhistidine) have been reported to show antioxidant and ACE inhibitory activities (Hou et al. 2003; Marušić et al. 2013).

ACE inhibitory peptides are the most studied bioactive peptides due to their ability to prevent hypertension, which is an important risk factor in the development of cardiovascular diseases. ACE-I is a dipeptidyl carboxypeptidase enzyme that converts angiotensin-I into the vasoconstrictor angiotensin-II in the renin-angiotensin system (RAS) as well as inactivates the vasodilator bradykinin (Wu et al. 2017). In silico approaches have been widely used to study the generation of $\mathrm{ACE}$ 
Table 1 Sequences of potential dipeptides and tripeptides naturally generated from different muscle proteins during the processing of Spanish dry-cured hams

\begin{tabular}{|c|c|c|c|c|c|c|}
\hline & Protein of origin & Abbreviation & $\begin{array}{l}\mathrm{MW} \\
(\mathrm{Da})^{\mathrm{a}}\end{array}$ & Dipeptides & Tripeptides & References \\
\hline \multirow[t]{11}{*}{$\begin{array}{l}\text { Sarcoplasmic } \\
\text { proteins }\end{array}$} & \multirow[t]{2}{*}{ Creatine Kinase } & \multirow[t]{2}{*}{ CK } & \multirow[t]{2}{*}{43,059} & $\mathrm{DL}, \mathrm{LA}, \mathrm{PD}, \mathrm{VE}, \mathrm{VQ}, \mathrm{VS}, \mathrm{YV}$ & AQK, GHP, HKT, SVF & $\begin{array}{l}\text { (Mora et al. } \\
\text { 2009a) }\end{array}$ \\
\hline & & & & $\mathrm{DR}, \mathrm{EN}, \mathrm{HP}, \mathrm{PL}, \mathrm{IM}, \mathrm{IQ}, \mathrm{VF}$ & ALN, DPN, GHP, HGG, KLR, VGS & $\begin{array}{l}\text { (Mora et al. } \\
\text { 2016) }\end{array}$ \\
\hline & \multirow[t]{2}{*}{ Enolase } & \multirow[t]{2}{*}{ ENO } & \multirow[t]{2}{*}{47,100} & VY & LYK, RDG & $\begin{array}{l}\text { (Mora et al. } \\
2011 \text { a) }\end{array}$ \\
\hline & & & & $\mathrm{IL}, \mathrm{NP}$ & GNP & $\begin{array}{l}\text { (Mora et al. } \\
\text { 2015b) }\end{array}$ \\
\hline & \multirow[t]{2}{*}{$\begin{array}{l}\text { Glyceraldehyde 3-Phosphate } \\
\text { Dehydrogenase }\end{array}$} & \multirow[t]{2}{*}{ GAPDH } & \multirow[t]{2}{*}{37,624} & VK & CLA & $\begin{array}{l}\text { (Mora et al. } \\
2011 \text { a) }\end{array}$ \\
\hline & & & & $A Q, \| l, R G$ & $\| P, R G A$ & $\begin{array}{l}\text { (Mora et al. } \\
\text { 2015b) }\end{array}$ \\
\hline & Lactate Dehydrogenase & $\mathrm{LDH}$ & 36,596 & $\mathrm{LL}$ & & $\begin{array}{l}\text { (Mora et al. } \\
\text { 2011a) }\end{array}$ \\
\hline & Phosphoglycerate Mutase & PGAM & 28,667 & & VRK & $\begin{array}{l}\text { (Mora et al. } \\
2011 \mathrm{a} \text { ) }\end{array}$ \\
\hline & Ubiquitin-60S & UBQ & 14,728 & $\mathrm{DK}, \mathrm{IF}, \mathrm{KA}, \mathrm{RT}, \mathrm{SD}, \mathrm{VK}$ & DKE, GRT, IFA, KIQ, SDY, VKT & $\begin{array}{l}\text { (Mora et al. } \\
\text { 2015c) }\end{array}$ \\
\hline & \multirow[t]{2}{*}{ Myoglobin } & \multirow[t]{2}{*}{ MYG } & \multirow[t]{2}{*}{17,085} & $\mathrm{FK}, \mathrm{KH}$ & TPL & $\begin{array}{l}\text { (Mora and } \\
\text { Toldrá 2012) }\end{array}$ \\
\hline & & & & DE, EA, GK, HK, QL, SE, SK & $\mathrm{DAQ}, \mathrm{VLN}, \mathrm{YLE}$ & $\begin{array}{l}\text { (Mora et al. } \\
\text { 2016) }\end{array}$ \\
\hline \multirow[t]{11}{*}{$\begin{array}{l}\text { Myofibrillar } \\
\text { proteins }\end{array}$} & LIM Domain-Binding 3 & LDB3 & 35,589 & $\begin{array}{l}\mathrm{AL}, \mathrm{AQ}, \mathrm{AY}, \mathrm{GD}, \mathrm{IS}, \mathrm{LS}, \mathrm{LT}, \mathrm{MP}, \\
\mathrm{PA}, \mathrm{QG}, \mathrm{QL}, \mathrm{QP}, \mathrm{RL}, \mathrm{SA}, \mathrm{SQ}, \mathrm{W}\end{array}$ & $\begin{array}{l}\text { APA, AQS, EAQ, GKD, NMP, SQG, } \\
\text { SQL, STY, SVT, WGF }\end{array}$ & $\begin{array}{l}\text { (Gallego et } \\
\text { al. 2014b) }\end{array}$ \\
\hline & \multirow[t]{2}{*}{ Myosin Heavy Chain } & \multirow[t]{2}{*}{$\mathrm{MHC}$} & \multirow[t]{2}{*}{223,150} & $\begin{array}{l}\mathrm{AD}, \mathrm{AK}, \mathrm{DQ}, \mathrm{EQ}, \mathrm{GK}, \mathrm{KS}, \mathrm{KT}, \mathrm{IP}, \\
\mathrm{LQ}\end{array}$ & VNT & $\begin{array}{l}\text { (Mora et al. } \\
\text { 2016) }\end{array}$ \\
\hline & & & & AN, AT, FD, QT, TL, TS, VK & GKM, KIE, NAS, SRE, TVQ & $\begin{array}{l}\text { (Mora et al. } \\
\text { 2019) }\end{array}$ \\
\hline & \multirow[t]{3}{*}{ Myosin Light Chain } & \multirow[t]{3}{*}{ MLC } & \multirow[t]{3}{*}{20,918} & $A A, P A, A P$ & PAP & $\begin{array}{l}\text { (Mora et al. } \\
\text { 2009b) }\end{array}$ \\
\hline & & & & $\begin{array}{l}A D, A L, E K, F K, I E, I K, I N, K V \\
L G, L R, N P, P E, R D, T N, V F, V K\end{array}$ & $\begin{array}{l}\text { APA, EEM, EKL, LKG, NAE, RVF, } \\
\text { SGP, TNP, VLD }\end{array}$ & $\begin{array}{l}\text { (Mora et al. } \\
2011 b \text { ) }\end{array}$ \\
\hline & & & & $\mathrm{Al}, \mathrm{SN}$ & ELR & $\begin{array}{l}\text { (Mora et al. } \\
\text { 2016) }\end{array}$ \\
\hline & Myozenin & MYOZ & 31,667 & $\mathrm{AG}, \mathrm{SG}, \mathrm{SQ}$ & GAG, GPG & $\begin{array}{l}\text { (Mora et al. } \\
2015 b \text { ) }\end{array}$ \\
\hline & \multirow[t]{2}{*}{ Titin (fragments) } & \multirow[t]{2}{*}{ TTN } & \multirow[t]{2}{*}{381,603} & $\mathrm{KV}$ & & $\begin{array}{l}\text { (Mora et al. } \\
\text { 2009b) }\end{array}$ \\
\hline & & & & $\begin{array}{l}\text { AK, DE, EA, EE, El, EP, GP, KA, } \\
K P, P A, P E, P K, P P, S V, V E, V K\end{array}$ & $\begin{array}{l}\text { AKK, APF, DAV, DEI, EAK, EPE, } \\
\text { IEA, IKG, KAV, KDE, KER, MLK, } \\
\text { PKE, PPI, PSP, PTP, RKK, STS, SVL, } \\
\text { TPK, VKF }\end{array}$ & $\begin{array}{l}\text { (Gallego et } \\
\text { al. 2015) }\end{array}$ \\
\hline & \multirow[t]{2}{*}{ Troponin T } & \multirow[t]{2}{*}{ TNT } & \multirow[t]{2}{*}{32,176} & $A P, I P, N K$ & & $\begin{array}{l}\text { (Mora et al. } \\
\text { 2010) }\end{array}$ \\
\hline & & & & $\mathrm{El}, \mathrm{IQ}, \mathrm{VH}$ & & $\begin{array}{l}\text { (Mora et al. } \\
\text { 2016) }\end{array}$ \\
\hline
\end{tabular}

${ }^{a}$ Theoretical molecular weight of the protein in Daltons

inhibitory peptides from different food proteins, reporting the high influence of the hydrophobicity, charge and size of the peptide sequence on binding ACE. So, the presence of hydrophobic residues such as $\mathrm{P}$ and $\mathrm{A}$, and the decreased side chain size of the amino acids close to the C-terminal region would enhance the ACE-inhibitorypotential of the peptide (Pripp et al. 2004; $\mathrm{Gu}$ et al. 2011). Focusing on short peptides, regression models have shown that dipeptides containing amino acid residues with bulky and hydrophobic side chains, and 
Table 2 Sequences of dry-cured ham-derived dipeptides and tripeptides presenting bioactivity according to the BIOPEP database (access May 2019)

\begin{tabular}{|c|c|c|c|c|c|c|c|c|}
\hline \multirow[b]{2}{*}{$\begin{array}{l}\text { Peptide } \\
\text { sequence }^{a}\end{array}$} & \multirow[b]{2}{*}{$\begin{array}{l}\text { Mass } \\
(\mathrm{Da})^{\mathrm{b}}\end{array}$} & \multirow[b]{2}{*}{$\begin{array}{l}\text { Protein } \\
\text { of origin }\end{array}$} & \multicolumn{6}{|c|}{ Bioactivity } \\
\hline & & & $\begin{array}{l}\text { ACE } \\
\text { inhibitor }\end{array}$ & $\begin{array}{l}\text { Renin } \\
\text { inhibitor }\end{array}$ & $\begin{array}{l}\text { DPP IV } \\
\text { inhibitor }\end{array}$ & $\begin{array}{l}\text { Glucose uptake } \\
\text { stimulating }\end{array}$ & $\begin{array}{l}\text { Antioxidant } \\
\text { activity }\end{array}$ & $\begin{array}{l}\text { DPP III } \\
\text { inhibitor }\end{array}$ \\
\hline $\mathrm{AA}$ & 160.17 & MLC & $x$ & & $x$ & & & \\
\hline$A D$ & 204.18 & MLC, MHC & & & $x$ & & & \\
\hline$A G$ & 146.14 & MYOZ & $x$ & & $x$ & & & \\
\hline $\mathrm{Al}$ & 202.25 & MLC & $x$ & & & & & \\
\hline AKK & 345.44 & TTN & $x$ & & & & & \\
\hline $\mathrm{AL}$ & 202.25 & MLC, CK & & & $x$ & & & \\
\hline AP & 186.21 & MLC, TROP T & $x$ & & $x$ & & & \\
\hline AT & 190.20 & $\mathrm{MHC}$ & & & $x$ & & & \\
\hline$A Y$ & 252.27 & LDB3 & $x$ & & $x$ & & $x$ & \\
\hline EA & 218.21 & TTN, MYG & $x$ & & & & & \\
\hline EAK & 346.38 & TTN & & & & & $x$ & \\
\hline $\mathrm{EF}$ & 278.35 & UBQ & & $x$ & & & & \\
\hline $\mathrm{El}$ & 260.29 & TTN, TROP T & $x$ & & $x$ & & & \\
\hline EK & 275.30 & MLC & $x$ & & $x$ & & & \\
\hline EL & 244.33 & ENO & & & & & $x$ & \\
\hline EP & 244.25 & TTN & & & $x$ & & & \\
\hline GD & 190.15 & LDB3, CK & $x$ & & & & & \\
\hline GK & 203.24 & MYG, MHC & $x$ & & & & & \\
\hline GP & 172.18 & TTN & $x$ & & $x$ & & & \\
\hline$H K$ & 283.33 & MYG, CK & $x$ & & & & & $x$ \\
\hline $\mathrm{HP}$ & 252.27 & CK & $x$ & & $x$ & & & $x$ \\
\hline $\mathrm{IE}$ & 260.29 & MLC & $x$ & & & & & \\
\hline$\|$ & 244.33 & ENO & & & $x$ & $x$ & & \\
\hline IF & 278.35 & UBQ & $x$ & & & & & \\
\hline $\mathrm{IL}$ & 244.33 & ENO & $x$ & & $x$ & $x$ & & \\
\hline IM & 262.37 & CK & & & $x$ & & & \\
\hline IN & 245.28 & MLC & & & $x$ & & & \\
\hline $\mathbb{P}$ & 228.29 & MHC, TROP T & $x$ & & $x$ & & & \\
\hline IQ & 259.30 & CK, TROP T & & & $x$ & & & \\
\hline KA & 217.27 & TTN, UBQ & $x$ & & $x$ & & & $x$ \\
\hline $\mathrm{KH}$ & 283.33 & MYG & & & $x$ & & & \\
\hline KP & 243.30 & TTN & $x$ & & $x$ & & $x$ & \\
\hline KS & 233.27 & $\mathrm{MHC}$ & & & $x$ & & & \\
\hline KT & 247.29 & MHC & & & $x$ & & & \\
\hline KV & 245.32 & MLC, TTN & & & $x$ & & & \\
\hline LA & 202.25 & CK & $x$ & & $x$ & & & $x$ \\
\hline LG & 188.23 & MLC & $x$ & & & & & \\
\hline $\mathrm{LL}$ & 244.33 & $\mathrm{LDH}$ & & & $x$ & $x$ & & \\
\hline LQ & 259.30 & MHC & $x$ & & & & & \\
\hline$L R$ & 287.36 & MLC & $x$ & $x$ & & & & $x$ \\
\hline LT & 232.28 & LDB3 & & & $x$ & & & \\
\hline
\end{tabular}


Table 2 Sequences of dry-cured ham-derived dipeptides and tripeptides presenting bioactivity according to the BIOPEP database (access May 2019) (Continued)

\begin{tabular}{|c|c|c|c|c|c|c|c|c|}
\hline \multirow[b]{2}{*}{$\begin{array}{l}\text { Peptide } \\
\text { sequence }^{a}\end{array}$} & \multirow[b]{2}{*}{$\begin{array}{l}\text { Mass } \\
(\mathrm{Da})^{\mathrm{b}}\end{array}$} & \multirow[b]{2}{*}{$\begin{array}{l}\text { Protein } \\
\text { of origin }\end{array}$} & \multicolumn{6}{|c|}{ Bioactivity } \\
\hline & & & $\begin{array}{l}\text { ACE } \\
\text { inhibitor }\end{array}$ & $\begin{array}{l}\text { Renin } \\
\text { inhibitor }\end{array}$ & $\begin{array}{l}\text { DPP IV } \\
\text { inhibitor }\end{array}$ & $\begin{array}{l}\text { Glucose uptake } \\
\text { stimulating }\end{array}$ & $\begin{array}{l}\text { Antioxidant } \\
\text { activity }\end{array}$ & $\begin{array}{l}\text { DPP III } \\
\text { inhibitor }\end{array}$ \\
\hline $\mathrm{MP}$ & 246.33 & LDB3 & & & $x$ & & & \\
\hline NK & 260.29 & TROP T & $x$ & & & & & \\
\hline NP & 229.23 & MLC, ENO & & & $x$ & & & \\
\hline NR & 289.29 & CK & & $x$ & $x$ & & & \\
\hline PA & 186.21 & MLC,TTN, LDB3 & & & $x$ & & & \\
\hline PAP & 283.32 & MLC & $x$ & & & & & \\
\hline PE & 244.25 & MLC, TTN & & & & & & $x$ \\
\hline PK & 243.30 & TTN & & & $x$ & & & \\
\hline$P L$ & 228.29 & CK & $x$ & & $x$ & & & \\
\hline PP & 212.25 & TTN & $x$ & & $x$ & & & \\
\hline QG & 203.20 & LDB3 & $x$ & & $x$ & & & \\
\hline QL & 259.30 & LDB3, MYG & & & $x$ & & & \\
\hline QP & 243.26 & LDB3 & & & $x$ & & & \\
\hline RG & 231.25 & ENO & $x$ & & $x$ & & & \\
\hline $\mathrm{RL}$ & 287.36 & LDB3 & $x$ & & $x$ & & & \\
\hline SG & 162.14 & MYOZ & $x$ & & & & & \\
\hline SGP & 259.26 & MLC & $x$ & & & & & \\
\hline SK & 233.27 & MYG & & & $x$ & & & \\
\hline SV & 204.22 & TTN & & & $x$ & & & \\
\hline TD & 234.10 & CK & & & $x$ & & & \\
\hline $\mathrm{TL}$ & 232.28 & $\mathrm{MHC}$ & & & $x$ & & & \\
\hline $\mathrm{TN}$ & 233.22 & MLC & & & $x$ & & & \\
\hline TNP & 330.34 & MLC & $x$ & & & & & \\
\hline TS & 206.20 & $\mathrm{MHC}$ & & & $x$ & & & \\
\hline VE & 246.26 & TTN, CK & $x$ & & $x$ & & & \\
\hline VF & 264.32 & MLC, CK & $x$ & & $x$ & & & \\
\hline $\mathrm{VH}$ & 254.29 & TROP T & & & $x$ & & & \\
\hline VK & 245.32 & MLC, TTN, GAPDH, MHC, UBQ & $x$ & & $x$ & & & \\
\hline VQ & 245.28 & CK & & & $x$ & & & \\
\hline VS & 204.22 & CK & & & $x$ & & & \\
\hline W & 216.28 & LDB3 & & & $x$ & & & \\
\hline VY & 280.32 & ENO & $x$ & & $x$ & & $x$ & $x$ \\
\hline Y & 280.32 & CK & $x$ & & $x$ & & & \\
\hline
\end{tabular}

Other bioactivities of the dipeptides. GP: antitrombotic, antiamnestic, and regulator of stomach mucosal membrane activity; EE: stimulating vasoactive substance release; EF: CaMPDE inhibition; LA: activating ubiquitin-mediated proteolysis

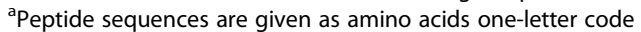

${ }^{b}$ Mass of the peptide sequence in Daltons calculated using PeptideMass from ExPASy

'Possible proteins of origin of the peptides. Names of the abbreviated proteins are given in Table 1

tripeptides with aromatic amino acids at the C-terminal, positively charged amino acids in the middle position, and hydrophobic amino acids at the $\mathrm{N}$-terminal were more favorable for ACE inhibition (Wu et al. 2006). As can be seen in Table 2, numerous dipeptides as well as the tripeptide AKK derived from titin, and PAP, SGP, and TNP from myosin light chain protein would show ACEinhibition. A previous study evaluated the ACE inhibitory activity of several dipeptides generated by the action of DPP enzymes during the dry-cured ham processing, 
reporting the effectiveness of RP, KA, GP, and AA as ACE inhibitors (Sentandreu and Toldrá 2007).

Renin inhibitors represent an alternative to ACE inhibitors to exert hypotensive effects because they inhibit the RAS at its first and rate limiting step, in which the enzyme renin cleavages angiotensinogen to generate angiotensin I (Pihlanto and Mäkinen 2017). The presence of N-terminal hydrophobic low molecular weight amino acids such as I, L, A, or V, and C-terminal bulky residues such as $\mathrm{W}, \mathrm{F}$, or $\mathrm{Y}$ potentiate renin inhibition (Pihlanto and Mäkinen 2017). So, the lowering blood pressure action of ACE inhibitory and renin inhibitory peptides would be interesting for their use as natural agents for the management of hypertension. The dipeptide LR could present hypotensive activity in view of ACE and renin inhibition, whereas NR and EF would only act as renin inhibitors (Table 2). Several peaderived dipeptides including IR, LR, or LW showed renin inhibition, and IW was found to be a potent renininhibiting dipeptide and an effective ACE inhibitor (Udenigwe and Aluko 2012). However, according to our knowledge, no dry-cured ham-derived peptides presenting renin inhibitory activity have been described to date.

The enzyme DPP IV degrades and inactivates the incretin hormones glucagon-like peptide-1 (GLP-1) and glucose-dependent insulinotropic polypeptide (GIP), which are involved in the release of glucose-stimulated insulin, suppression of glucagon secretion, and improvement of plasma glucose levels. So, DPP IV inhibitory peptides would represent a nutritional strategy for the treatment of type 2 diabetes (Power et al. 2014). Additionally, peptides can stimulate glucose uptake in skeletal muscles through other molecular pathways independently of insulin or by increasing insulin sensitivity in target cells, resulting in increased skeletal muscle glycogen contents. Dipeptides containing branched-chain amino acids such as II, IL, IV, LI and LL have been reported to present this activity possibly via kinase signaling pathways, which are different from the mechanism of the insulin-stimulated glucose transporters (Morifuji et al. 2009). As can be seen in Table 2, more than 50 of the evaluated dipeptides and tripeptides would present DPP IV inhibition according to the BIOPEP database. Furthermore, the enolase-derived dipeptides II and IL as well as LL from lactate dehydrogenase could exert positive effects on glucose regulation by both DPP IV inhibition and stimulating glucose uptake activity (Table 2). A previous in silico approach reported the high potential of food proteins such as milk casein and bovine collagen as precursors of DPP-IV inhibitory peptides, with GA, GP, and PG being the most frequently occurring sequences (Lacroix and Li-Chan 2012). Spanish dry-cured hams have also been described as a source of DPP IV inhibitory dipeptides such as AA, GP, and KA (Gallego et al. 2014a). It has been reported that DPP IV inhibitory peptides contain mainly P and/or hydrophobic amino acids within their sequence and that the N-terminal residue plays a crucial role in determining their inhibitory activity (Lacroix and Li-Chan 2012).

Antioxidant peptides can scavenge or quench reactive oxygen species (ROS) and/or free radicals as well as inhibit ROS induced-oxidation of macromolecules such as lipids, proteins, and DNA (Huang et al. 2005). The molecular mass, composition and location of amino acids in the sequence, structure, and hydrophobicity of the peptide greatly determine its effectiveness to act as antioxidant and the mechanism underlying this activity. So, dipeptides and tripeptides containing W, Y, C, and $M$ residues such as YG, WQ, or GTW have been described to show high radical scavenging activities, although the neighboring residue/s would affect their bioactivity by steric effect, hydrophobicity and hydrogen bonding (Tian et al. 2015; Zheng et al. 2016). Dry-cured ham peptides AY, EL, KP, VY, and EAK would present antioxidant activity according to the BIOPEP database (Table 2).

Dipeptidyl peptidase III presents high affinity to cleave opioid peptides such as enkephalins and endomorphins. These opioid peptides regulate diverse physiological functions such as signal transduction, gastrointestinal motility, immune and endocrine functions, and mostly pain modulation. Dipeptides with aromatic residues such as YY, YF, and containing large aliphatic or basic amino acids have been described as potent inhibitors (Khaket et al. 2015). Few studies have identified DPP III inhibitory peptides from meat proteins, however, hemoglobin could present a high potential as source of such bioactive peptides (Khaket et al. 2015). In dry-cured hams, creatine kinase-derived dipeptides such as HK, HP, and LA would show DPP III inhibitory activity according to the BIOPEP database (Table 3).

\section{Taste of dipeptides and tripeptides}

The pleasant dry-cured ham taste results from an adequate balancing of enzymatic activities and thus of the generated taste-active compounds (Toldrá and Flores 1998; Sforza et al. 2006). Pork meat proteins present a high potential for the generation of sensory peptides and free amino acids, and their effect on ham flavour. The influence of the processing time, enzymes, and hydrolysis conditions on the sensory traits of dry-cured hams have been widely studied (Flores et al. 1997; Ruiz et al. 1998; Soresi Bordini et al. 2004; Del Olmo et al. 2013). Bitter, sweet, and umami tastes are mainly attributable to peptides, whereas salty and sour tastes are related to the charge or amino acid side chains of the peptides (Iwaniak et al. 2016b). Numerous dipeptides and tripeptides have 
Table 3 Sequences of dry-cured ham-derived dipeptides and tripeptides imparting taste characteristics according to the BIOPEP database (access May 2019)

\begin{tabular}{|c|c|c|c|c|c|c|c|c|c|c|c|}
\hline \multirow[b]{2}{*}{$\begin{array}{l}\text { Peptide } \\
\text { sequence }^{\text {a }}\end{array}$} & \multirow[b]{2}{*}{$\begin{array}{l}\text { Mass } \\
(\mathrm{Da})^{\mathrm{b}}\end{array}$} & \multirow[b]{2}{*}{$\begin{array}{l}\text { Proteins of } \\
\text { originc }^{c}\end{array}$} & \multicolumn{9}{|l|}{ Taste } \\
\hline & & & Bitter & Umami & Salty & Sour & Sweet & $\begin{array}{l}\text { Bitterness } \\
\text { supressing }\end{array}$ & $\begin{array}{l}\text { Sweetness } \\
\text { supressing }\end{array}$ & $\begin{array}{l}\text { Umami } \\
\text { enhancing }\end{array}$ & $\begin{array}{l}\text { Salty } \\
\text { enhancing }\end{array}$ \\
\hline$\overline{\mathrm{AA}^{*}}$ & 160.17 & MLC & & & & & $x$ & & & & \\
\hline$A D^{*}$ & 204.18 & MLC & $x$ & $x$ & & & & & & & \\
\hline $\mathrm{DE}$ & 262.22 & TTN, MYG & & $x$ & $x$ & $x$ & & & & & \\
\hline $\mathrm{DL}$ & 246.26 & CK & $x$ & $x$ & & & & & & & \\
\hline$E A^{*}$ & 218.21 & TTN, MYG & $x$ & $x$ & & & & & & & \\
\hline $\mathrm{EE}$ & 276.24 & TTN & $x$ & $x$ & $x$ & & & $x$ & $x$ & & \\
\hline $\mathrm{EF}^{*}$ & 278.35 & UBQ & $x$ & & & & & & & & \\
\hline$E l^{*}$ & 260.29 & TTN & $x$ & & & & & & & & \\
\hline$E K^{*}$ & 275.30 & MLC & & $x$ & & & & & & & \\
\hline$E L^{*}$ & 244.33 & ENO & $x$ & & & & & & & & \\
\hline GAG & 203.20 & MYOZ & & & & & $x$ & & & & \\
\hline $\mathrm{GP}^{*}$ & 172.18 & $\pi N$ & $x$ & & & & & & & & \\
\hline GPG & 229.23 & MYOZ & $x$ & & & & & & & & \\
\hline$\|^{*}$ & 244.33 & ENO & $x$ & & & & & & & & \\
\hline $\mathrm{IL}^{*}$ & 244.33 & ENO & $x$ & & & & & & & & \\
\hline$K P^{*}$ & 243.30 & TTN & $x$ & & & & & & & & \\
\hline$L A^{*}$ & 202.25 & CK & $x$ & & & & & & & & \\
\hline $\mathrm{LG}^{*}$ & 188.23 & MLC & $x$ & & & & & & & & \\
\hline$L L^{*}$ & 244.33 & LDH & $x$ & & & & & & & & \\
\hline$P A^{*}$ & 186.21 & $\begin{array}{l}\text { MLC, TTN, } \\
\text { LDB3 }\end{array}$ & $x$ & & & & & & & & \\
\hline$P E^{*}$ & 244.25 & MLC, TTN & & & & & & & & $x$ & \\
\hline $\mathrm{PK}^{*}$ & 243.30 & TTN & $x$ & & & & & & & & \\
\hline$P L^{*}$ & 228.29 & CK & $x$ & & & & & & & & \\
\hline$P P^{*}$ & 212.25 & TTN & $x$ & & & & & & & & \\
\hline $\mathrm{RG}^{*}$ & 231.25 & ENO & $x$ & & & & & & & & $x$ \\
\hline$V E^{*}$ & 246.26 & TTN, CK & $x$ & $x$ & & $x$ & & & & & \\
\hline$V F^{*}$ & 264.32 & MLC, CK & $x$ & & & & & & & & \\
\hline$W^{*}$ & 216.28 & LDB3 & $x$ & $x$ & & & & & & & \\
\hline$V^{*}$ & 280.32 & ENO & $x$ & & & & & & & & \\
\hline
\end{tabular}

*Peptides presenting both bioactivity and taste. The bioactivities of these peptides are shown in Table 2

a Peptide sequences are given as amino acids one-letter code

b Mass of the peptide sequence in Daltons calculated using PeptideMass from ExPASy

c Possible proteins of origin of the peptides. Names of the abbreviated proteins are given in Table 1

been associated with taste sensations, while the identification of longer peptide sequences contributing directly to the taste of dry-cured meats is limited to date. As examples, the peptides CCNKSV from Jinhua ham and AHSVRFY from Parma ham were reported as mainly responsible for the umami taste of their respective water-soluble ham extracts based on sensory evaluation by taste dilution analysis and electronic tongue (Dang et al. 2015).
Bioinformatics tools enable a fast and cheaper prediction of the generation of sensory peptides and amino acids in foods. Focusing on dry-cured meat products, a recent in silico study has shown that myofibrillar proteins generate more taste-active peptides than sarcoplasmic proteins. The myofibrillar proteins myosin-2 and nebulin, and the sarcoplasmic proteins creatine kinase and alpha-1,4 glucan phosphorylase would yield the greatest number of peptides and free amino acids 
with sensory activity, mainly giving bitter and umami taste (Kęska and Stadnik 2017). Table 3 reports the sequences of dry-cured hams dipeptides and tripeptides showing taste characteristics (bitter, umami, salty, sour, sweet, taste suppressors and taste enhancers) according to the BIOPEP database. The probable proteins of origin of such taste-active peptides are also indicated. Most of the studied dipeptides provide bitter taste, followed by umami peptides, and they would come from the degradation of the long-chain titin, but also from myosin and creatine kinase in agreement with previous studies (Kęska and Stadnik 2017).

Bitterness is the most common taste associated with protein hydrolysis, and it is attributable to peptides rather than free amino acids (Maehashi and Huang 2009). Peptides giving bitter taste have been reported to contain branched side chain and hydrophobic amino acids such as L, I, V, F, and Y, as well as containing neutral amino acids with aromatic or basic residues. Regression models have determined that hydrophobic amino acids at the C-terminus and bulky amino acid residues adjacent to this position are the major determinants of the intensity of bitterness of dipeptides and tripeptides (Wu and Aluko 2007). As an example, dipeptides RP, AF, VV, LY, KA, and HH have been described to impart bitterness in foodstuffs (Kirimura et al. 1969). Focusing on dry-cured hams, the dipeptides GF, GL, and LL (where L could be I) identified in Parma hams, as well as IV, LE, ID, and PL in Serrano dry-cured hams were associated with a bitter taste (Sentandreu et al. 2003; Sforza et al. 2001). Table 3 shows the sequences of several bitter dry-cured ham dipeptides such as AD, LG, $\mathrm{PA}$, and VF derived from myosin light chain protein, EL, II, RG and VY from enolase, or the tripeptide GPG from myozenin protein. It should be considered that an accumulation of bitter peptides could generate an undesired taste in hams, but it can be counteracted by other taste compounds such as those peptides rich in E residues. In this regard, $\gamma$-glutamyl dipeptides such as EI, EL or EF identified in Parma dry-cured hams (Sforza et al. 2006) and the titin-derived dipeptide EE (Table 3) could act as bitterness suppressors.

The sour taste is mainly associated with peptides having acidic amino acids ( $\mathrm{E}$ and $\mathrm{D}$ ), but also with the presence of acidic and neutral or aromatic residues in the peptide sequence. Dipeptides AD, EE, GD, or EF, among others, have been described to give sourness in foods (Kirimura et al. 1969), whereas dipeptides DV, GE, and VE could be responsible for a sour taste in Spanish dry-cured hams (Sentandreu et al. 2003). The dipeptide VE could be generated due to the degradation of titin and/or creatine kinase proteins, whereas DE derived from titin and/or myoglobin could also be responsible for sourness (Table 3 ).
The aged taste is a good accepted trait in dry-cured hams that would be related with the brothy/umami taste given by peptides containing $\mathrm{E}$ or $\mathrm{D}$ amino acids (Nishimura and Kato 1988). Dipeptides and tripeptides rich in D greatly increased during the long aging of hams and thus could act as permanent taste-active compounds. The dipeptide EY was related to aged taste in Parma hams (Sforza et al. 2001), ER could provide umami taste to Spanish dry-cured hams (Sentandreu et al. 2003), and VE, PE, DGG, and PAQ were described as umami peptides present in aging hams (Dang et al. 2015). Up to date, a large number of umami dipeptides and tripeptides derived from pork meat proteins have been identified (Kęska and Stadnik 2017), as for example the titin-derived dipeptides DE, EA, EE, EK, PK, and VE (Table 3).

The salty taste is mainly associated with the acidic amino acid D, and several dipeptides and tripeptides such as DD, DE, ED, EE, DEE, or DES derived from pork meat proteins have been reported to give this sensory activity (Kęska and Stadnik 2017). DE and EE could come from titin protein, although the degradation of myoglobin during dry-cured ham processing could also generate the dipeptide DE (Table 3). Conversely, peptides containing the hydrophobic amino acids $\mathrm{A}, \mathrm{P}$, and $\mathrm{V}$, and/or the hydrophilic residues $\mathrm{K}$ and $\mathrm{G}$, such as peptides AA, EV, AAA, AGA, and GAG have been reported to give sweet taste (Kęska and Stadnik 2017). As can be seen in Table 3, the sweet dipeptide AA and the tripeptide GAG could come from myosin and myozenin proteins, respectively. It should be highlighted the unique role of peptides as sour and sweet suppressors as well as salty and umami enhancers, as it has not been observed for free amino acids. In this regard, the dipeptide EE has been described as both bitter and sweet suppressor, PE as umami enhancer, and RG as salty enhancer (Table 3). Porcine troponin T-derived peptides containing the sequence APPPPAEVHEV have been described as sour suppressors (Okumura et al. 2004), but no dipeptides or tripeptides showing this sensory characteristic have been reported to date.

The structure of sensory peptides does not always encode the amino acids responsible for taste sensation. Peptide sequences such as EE and EEE as well as dipeptides VV and PT present in Parma hams were associated with saltiness despite that they do not contain the amino acid D. Other peptides such as ED, EE, ES, DES, and EGS that suppress bitterness do not contain the tastequenching amino acids $\mathrm{R}$ and $\mathrm{K}$ responsible for this taste (Kęska and Stadnik 2017; Sforza et al. 2001), but it is likely due to interactions of umami peptides with receptors of other tastes (Iwaniak et al. 2016b). Furthermore, some peptides can have more than one sensory characteristic as for example, DE that can give umami, salty, and sour tastes, or VE that impart bitter, umami, and 
sour tastes (Table 3). It has been reported that umami has a great synergistic taste effect, so that it has the taste activity itself and may also enhance the other tastes of food (it makes the sugar sweeter, makes the salt saltier, and reduces the bitter and sour tastes) (Dang et al. 2014).

\section{Multifunctionality of dipeptides and tripeptides}

Some food-derived peptides have been described to be multifunctional as they can exert two or more healthpromoting activities that may or may not be related (Udenigwe and Aluko 2012; Aguilar-Toalá et al. 2017; Lammi et al. 2019). The diversified structures of peptides may interfere with different biochemical pathways, explaining the wide range of functional activities performed by food peptides. Moreover, the amino acid composition, sequence, and length. So, short-chain peptides may exert different bioactivities such as ACE inhibition and antioxidant activity, whereas those longer than 8 amino acids may participat for instance in the cholesterol biosynthesis pathway (Lammi et al. 2019). Proteins containing a high proportion of hydrophobic and positively charged residues could also be a good source of multifunctional peptides (Rao et al. 2012). As seen in Table 2, several dipeptides can present more than one bioactivity, mainly showing dual ACE and DPP IV inhibition. Furthermore, the bioactivity of peptides is often associated with sensory characteristics, and several studies have compared bioactivity and taste of protein hydrolysates (Iwaniak et al. 2016b). A total of 24 of the studied dipeptides presented both bioactivity and taste characteristics and they have been indicated with an asterisk in Table 3. As an example, dipeptides EI, GP, PL, PP, RG, and VF have been described to exert both ACE and DPP IV inhibitory activities as well as to impart bitterness. It has been described that ACE inhibitory peptides are often carriers of undesired bitter tastes, and regression models have determined that this dual function could be attributed to the presence of G, V, I, or L at $\mathrm{N}$-terminal, and $\mathrm{P}, \mathrm{Y}$, or $\mathrm{F}$ at $\mathrm{C}$-terminal of the peptide sequence (Hrynkiewicz et al. 2019). Nevertheless, other in silico approaches have shown no significant correlation between the bitterness of dipeptides and tripeptides and their ACE inhibitory properties (Wu and Aluko 2007; Hrynkiewicz et al. 2019). Other example includes dipeptides such as $\mathrm{AD}$ and VV that could give bitter and umami tastes as well as show bioactivity like DPP IV inhibition. Interestingly, the dipeptide VE has been described to exert both ACE and DPP IV inhibition as well as impart several tastes such as bitter, umami, and sour (Table 4). The identification of the active domain within the peptide sequence through the use of bioinformatics tools could help to characterise the molecular mechanism of action of multifunctional peptides, improving their potential use in the development of functional foods or dietary supplements (Lammi et al. 2019).

\section{Challenges in the study of dipeptides and tripeptides}

The use of bioinformatics approaches allows a fast prediction of the structure-activity relationship of peptides; however, the obtained results can differ due to the update of databases as well as the used programs and models using different variables and methods to measure bioactivity. For instance, the programs used for in silico assays cannot consider all the conditions of enzymatic reactions, nature of protein-enzyme interactions, and full characteristics of enzymes, being necessary to perform in vitro and in vivo studies to confirm the theoretical results (Udenigwe 2014).

Another factor to consider is the bioavailability of the peptides, as they can lose, maintain or gain bioactivity during gastrointestinal digestion and intestinal absorption. Dipeptides and tripeptides can be transported intact across the intestinal epithelium by peptide transporters like PepT1, but their ability to resist enzymatic hydrolysis depends in part on their amino acid composition (Segura-Campos et al. 2011). In this regard, dipeptides and oligopeptides containing the amino acid $\mathrm{P}$ in the C-terminal position have been reported to be more resistant to proline-specific peptidases (FitzGerald and Meisel 2000), whereas dipeptides with W at C-terminal could be hydrolysed by brush border peptidases before PepT1-mediated transport (Ano et al. 2004). Also blood plasma enzymes can degrade peptides, as for example, the aminopeptidases present in rat and human plasma could hydrolyse the ACE-inhibitory peptide IVY into the dipeptide VY, also with ACE-inhibitory activity (Matsui et al. 2000).

Additionally, peptides can undergo structural changes and reactions with components of the food matrix, which can reduce their bioavailability and bioaccessibility as well as modify their biological activities or sensory characteristics. ROS, Maillard reactions, and lipid oxidation products generated during food processing or enzymatic processes can modify the side chain of the amino acid residues of peptides, leading to the formation of disulphide linkages, Amadori products, dimers, polymers, or other derivatives (Udenigwe and Fogliano 2017). Moreover, the molecular composition of peptides can also play a role in this process, for instance, the presence of hydrophobic amino acids such as I, L, or F in lysinecontaining dipeptides would increase the reactivity of the residue $\mathrm{K}$, whereas the opposite was observed with basic amino acids (Mennella et al. 2006).

The use of empirical approaches comprising the identification and quantification of dipeptides and 


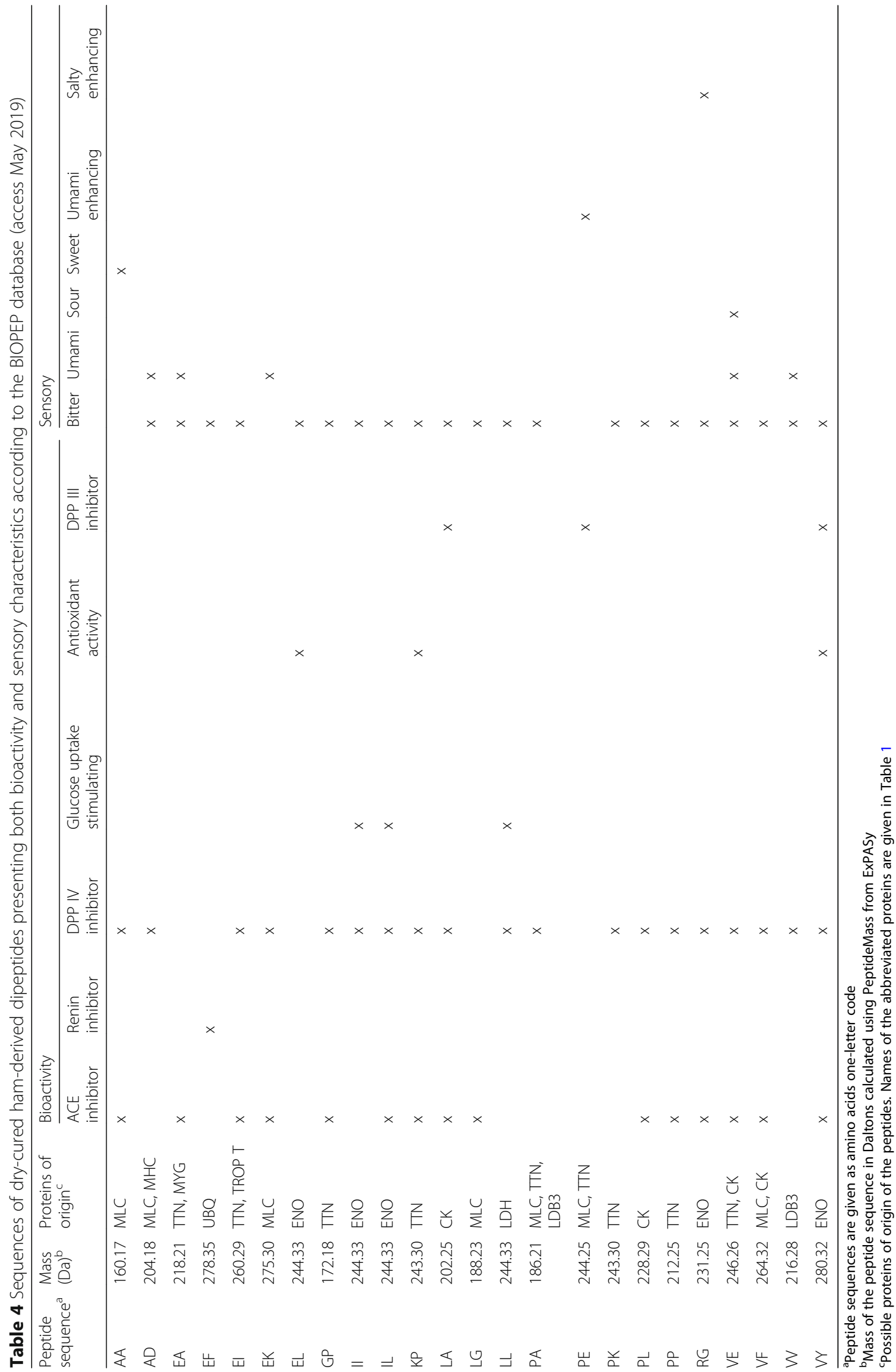


tripeptides by MS techniques is necessary in order to study the amount of peptide present in food, evaluate its bioavailability, and establish the dose needed to exert an in vivo effect in the case of bioactive peptides (Mora et al. 2017). Moreover, the new sensoproteomics approach, which combines sensory evaluation with instrumental analysis, is very useful to identify the taste-active key peptides and monitor their evolution during food processing (Sebald et al. 2018). Nonetheless, the small size and low concentration of peptides, complexity of the matrix sample, peptide interferences, and signal suppression due to the matrix effects make the peptidomics analysis rather complicated (Mora et al. 2017). Major challenges in the analysis of short peptides are due to: a) the wide range of polarity and different retention times during chromatographic separation because of matrix interactions; b) most of the ions generated by electrospray ionisation are singly charged and the fragmentation for MS detection is limited; and c) short peptide sequences cannot be confidently identified in database searches as they are not unique. So, the use of different separation strategies, modern and accurate MS instruments, and accurate optimisation of the MS parameters are needed to achieve an efficient analysis of dipeptides and tripeptides in complex samples (van Platerink et al. 2008; Stressler et al. 2013; Piovesana et al. 2019).

\section{Conclusions}

Bioinformatics can be combined with empirical approaches for a comprehensive search for peptides present in complex samples such as dry-cured ham. In silico analysis using the BIOPEP database results very useful to predict the generation of bioactive and tasteactive dipeptides and tripeptides derived from dry-cured hams. Most of these small peptides have been described to show in vitro ACE inhibitory or DPP IV inhibitory activities as well as impart bitterness. Moreover, each peptide can exert more than one bioactivity and/or taste, and there could even be a correlation between both as described, for example, for ACE inhibitory and bitter peptides. Nevertheless, empirical assays including in vitro and in vivo studies are necessary to confirm the theoretical results, considering food matrix interactions that can reduce their bioavailability and bioaccessibility and modify their biological activities and/or sensory characteristics, as well as the possible degradation of the peptide sequences by gastrointestinal enzymes during digestion and intestinal absorption.

\section{Acknowledgements}

Grant AGL2017-89381-R and FEDER funds from the Spanish Ministry of Economy, Industry and Competitiveness are acknowledged. Ramón y Cajal postdoctoral contract to LM is also acknowledged.

\section{Authors' contributions}

All authors contribued equally to the preparation of this manuscript. All authors read and approved the final manuscript.

\section{Funding}

Funds received from grant AGL2017--89381-R and FEDER funds from the Spanish Ministry of Economy, Industry and Competitiveness. Ramón y Cajal postdoctoral contract to LM was also received. These sources of funding did not have any role in the design of the study and collection, analysis, and interpretation of data and in writing the manuscript.

\section{Availability of data and materials}

This is a Review manuscript and all datasets on which the conclusions of the manuscript rely are included in the tables of the manuscript.

\section{Competing interests}

The authors declare that they have no competing interests.

Received: 14 June 2019 Accepted: 26 July 2019

Published online: 03 September 2019

\section{References}

Aguilar-Toalá, J. E., Santiago-López, L., Peres, C. M., Peres, C., Garcia, H. S., VallejoCordoba, B., González-Córdova, A. F., \& Hernández-Mendoza, A. (2017). Assessment of multifunctional activity of bioactive peptides derived from fermented milk by specific Lactobacillus plantarum strains. J Dairy Sci, 100(1), 65-75.

Ano, R., Kimura, Y., Urakami, M., Shima, M., Matsuno, R., Ueno, T., \& Akamatsu, M. (2004). Relationship between structure and permeability of dipeptide derivatives containing tryptophan and related compounds across human intestinal epithelial (Caco-2) cells. Bioorg Med Chem, 12(1), 249-255.

Dang, Y., Gao, X., Ma, F., \& Wu, X. (2015). Comparison of umami taste peptides in water-soluble extractions of Jinhua and Parma hams. LWT-Food Sci Technol, 60(2), 1179-1186

Dang, Y., Gao, X., Xie, A., Wu, X., \& Ma, F. (2014). Interaction between umami peptide and taste receptor T1R1/T1R3. Cell Biochem Biophys, 70(3), 1841-1848.

Degnes, K. F., Kvitvang, H. F. N., Haslene-Hox, H., \& Aasen, I. M. (2017). Changes in the profiles of metabolites originating from protein degradation during ripening of dry cured ham. Food Bioproc Tech, 10(6), 1122-1130.

Del Olmo, A., Calzada, J., Gaya, P., \& Nuñez, M. (2013). Proteolysis, texture, and sensory characteristics of serrano hams from duroc and large white pigs during dry-curing. J Food Sci, 78(3), C416-C424.

Escudero, E., Mora, L., Fraser, P. D., Aristoy, M. C., Arihara, K., \& Toldrá, F. (2013a). Purification and identification of antihypertensive peptides in Spanish drycured ham. J Proteome, 78, 499-507.

Escudero, E., Mora, L., Fraser, P. D., Aristoy, M. C., \& Toldrá, F. (2013b). Identification of novel antioxidant peptides generated in Spanish dry-cured ham. Food Chem, 138(2-3), 1282-1288.

FitzGerald, R. J., \& Meisel, H. (2000). Milk protein-derived peptide inhibitors of angiotensin-I-converting enzyme. Br J Nutr, 84(S1), 33-37.

Flores, M., Aristoy, M. C., Spanier, A. M., \& Toldrá, F. (1997). Non-volatile components effects on quality of "serrano" dry-cured ham as related to processing time. J Food Sci, 62(6), 1235-1239.

Gallego, M., Aristoy, M. C., \& Toldrá, F. (2014a). Dipeptidyl peptidase IV inhibitory peptides generated in Spanish dry-cured ham. Meat Sci, 96, 757-761.

Gallego, M., Mora, L., Aristoy, M. C., \& Toldrá, F. (2015). Titin-derived peptides as processing time markers in dry-cured ham. Food Chem, 167, 326-339.

Gallego, M., Mora, L., Fraser, P. D., Aristoy, M. C., \& Toldrá, F. (2014b). Degradation of LIM domain-binding protein three during processing of Spanish dry-cured ham. Food Chem, 149, 121-128.

Gallego, M., Mora, L., \& Toldrá, F. (2018). Perspectives in the use of peptidomics in ham. Proteomics, 18(18), 1700422.

Gu, Y., Majumder, K., \& Wu, J. (2011). QSAR-aided in silico approach in evaluation of food proteins as precursors of ACE inhibitory peptides. Food Res Int, 44(8), 2465-2474.

Hou, W. C., Chen, H. J., \& Lin, Y. H. (2003). Antioxidant peptides with angiotensin converting enzyme inhibitory activities and applications for angiotensin converting enzyme purification. J Agric Food Chem, 51(6), 1706-1709. 
Hrynkiewicz, M., Iwaniak, A., Bucholska, J., Minkiewicz, P., \& Darewicz, M. (2019) Structure-activity prediction of ACE inhibitory/bitter dipeptides - a chemometric approach based on stepwise regression. Molecules, 24(5), 950.

Huang, D., Ou, B., \& Prior, R. L. (2005). The chemistry behind antioxidant capacity assays. J Agric Food Chem, 53(6), 1841-1856.

Iwaniak, A., Minkiewicz, P., Darewicz, M., \& Hrynkiewicz, M. (2016b). Food proteinoriginating peptides as tastants-physiological, technological, sensory, and bioinformatic approaches. Food Res Int, 89, 27-38.

Iwaniak, A., Minkiewicz, P., Darewicz, M., Sieniawski, K., \& Starowicz, P. (2016a). BIOPEP database of sensory peptides and amino acids. Food Res Int, 85, 155-161.

Kęska, P., \& Stadnik, J. (2016). Porcine myofibrillar proteins as potential precursors of bioactive peptides-an in silico study. Food Funct, 7(6), 2878-2885.

Kęska, P., \& Stadnik, J. (2017). Taste-active peptides and amino acids of pork meat as components of dry-cured meat products: an in-silico study. J Sens Stud, 32(6), e12301.

Khaket, T. P., Redhu, D., Dhanda, S., \& Singh, J. (2015). In silico evaluation of potential DPP-III inhibitor precursors from dietary proteins. Int J Food Prop, 18(3), 499-507

Kirimura, J., Shimizu, A., Kimizuka, A., Ninomiya, T., \& Katsuya, N. (1969). Contribution of peptides and amino acids to the taste of foods. J Agric Food Chem, 17(4), 689-695.

Lacroix, I. M. E., \& Li-Chan, E. C. Y. (2012). Evaluation of the potential of dietary proteins as precursors of dipeptidyl peptidase (DPP)-IV inhibitors by an in silico approach. J Funct Foods, 4(2), 403-422.

Lafarga, T., \& Hayes, M. (2014). Bioactive peptides from meat muscle and byproducts: generation, functionality and application as functional ingredients. Meat Sci, 98(2), 227-239.

Lammi, C., Aiello, G., Boschin, G., \& Arnoldi, A. (2019). Multifunctional peptides for the prevention of cardiovascular disease: a new concept in the area of bioactive food-derived peptides. J Funt Foods, 55, 135-145.

Maehashi, K., \& Huang, L. (2009). Bitter peptides and bitter taste receptors. Cell Mol Life Sci, 66(10), 1661-1671.

Marušić, N., Aristoy, M. C., \& Toldrá, F. (2013). Nutritional pork meat compounds as affected by ham dry-curing. Meat Sci, 93(1), 53-60.

Matsui, T., Li, C. H., Tanaka, T., Maki, T., Osajima, Y., \& Matsumoto, K. (2000). Depressor effect of wheat germ hydrolysate and its novel angiotensin Iconverting enzyme inhibitory peptide, Ile-Val-Tyr, and the metabolism in rat and human plasma. Biol Pharm Bull, 23(4), 427-431.

Mennella, C., Visciano, M., Napolitano, A., Del Castillo, M. D., \& Fogliano, V. (2006). Glycation of lysine-containing dipeptides. J Pept Sci, 12(4), 291-296.

Miner-Williams, W. M., Stevens, B. R., \& Moughan, P. J. (2014). Are intact peptides absorbed from the healthy gut in the adult human? Nutr Res Rev, 27(2), 308-329.

Minkiewicz, P., Dziuba, J., Iwaniak, A., Dziuba, M., \& Darewicz, M. (2008). BIOPEP database and other programs for processing bioactive peptide sequences. $J$ AOAC Int, 91, 965-980.

Mora, L., Calvo, L., Escudero, E., \& Toldrá, F. (2016). Differences in pig genotypes influence the generation of peptides in dry-cured ham processing. Food Res Int, 86, 74-82.

Mora, L., Escudero, E., Arihara, K., \& Toldrá, F. (2015a). Antihypertensive effect of peptides naturally generated during Iberian dry-cured ham processing. Food Res Int, 78, 71-78.

Mora, L., Gallego, M., Aristoy, M. C., Fraser, P. D., \& Toldrá, F. (2015c). Peptides naturally generated from ubiquitin-60S ribosomal protein as potential biomarkers of dry-cured ham processing time. Food Control, 48, 102-107.

Mora, L., Gallego, M., Escudero, E., Reig, M., Aristoy, M. C., \& Toldrá, F. (2015b). Small peptides hydrolysis in dry-cured meats. Int J Food Microbiol, 212, 9-15.

Mora, L., Gallego, M., Reig, M., \& Toldrá, F. (2017). Challenges in the quantitation of naturally generated bioactive peptides in processed meats. Trends Food Sci Technol, 69, 306-314.

Mora, L., Gallego, M., \& Toldrá, F. (2019). Degradation of myosin heavy chain and its potential as a source of natural bioactive peptides in dry-cured ham. Food Biosci, 30, 100416

Mora, L., Sentandreu, M. A., Fraser, P. D., Toldrá, F., \& Bramley, P. M. (2009a). Oligopeptides arising the degradation of creatine kinase in Spanish drycured ham. J Agric Food Chem, 57, 8982-8988.

Mora, L., Sentandreu, M. A., Koistinen, K. M., Fraser, P. D., Toldrá, F., \& Bramley, P. M. (2009b). Naturally generated small peptides derived from myofibrillar proteins in serrano dry-cured ham. J Agric Food Chem, 57(8), $3228-3234$
Mora, L., Sentandreu, M. A., \& Toldrá, F. (2010). Identification of small troponin T peptides generated in dry-cured ham. Food Chem, 123(3), 691-697.

Mora, L., Sentandreu, M. A., \& Toldrá, F. (2011b). Intense degradation of myosin light chain isoforms in Spanish dry-cured ham. J Agric Food Chem, 59, 3884-3892.

Mora, L., \& Toldrá, F. (2012). Proteomic identification of small (<2000 Da) myoglobin peptides generated in dry-cured ham. Food Technol Biotechnol, 50(3), 343-349.

Mora, L., Valero, M. L., Del Pino, M. S., Sentandreu, M. A., \& Toldrá, F. (2011a). Small peptides released from muscle glycolytic enzymes during dry-cured ham processing. J Proteome, 74(4), 442-450.

Morifuji, M., Koga, J., Kawanaka, K., \& Higuchi, M. (2009). Branched-chain amino acid-containing dipeptides, identified from whey protein hydrolysates, stimulate glucose uptake rate in L6 myotubes and isolated skeletal muscles. J Nutr Sci Vitaminol, 55(1), 81-86.

Nishimura, T., \& Kato, H. (1988). Taste of free amino acids and peptides. Food Rev Int, 4(2), 175-194.

Okumura, T., Yamada, R., \& Nishimura, T. (2004). Sourness-suppressing peptides in cooked pork loins. Biosci Biotechnol Biochem, 68(8), 1657-1662.

Pihlanto, A., \& Mäkinen, S. (2017). The function of renin and the role of food-derived peptides as direct renin inhibitors. In A. N. Tolekova (Ed.), Renin-angiotensin system-past, present and future (pp. 241-258). London: InTech Open.

Piovesana, S., Montone, C. M., Cavaliere, C., Crescenzi, C., La Barbera, G., Laganà, A. , \& Capriotti, A. L. (2019). Sensitive untargeted identification of short hydrophilic peptides by high performance liquid chromatography on porous graphitic carbon coupled to high resolution mass spectrometry. J Chromatogr A, 1590, 73-79.

Power, O., Nongonierma, A. B., Jakeman, P., \& Fitzgerald, R. J. (2014). Food protein hydrolysates as a source of dipeptidyl peptidase IV inhibitory peptides for the management of type 2 diabetes. Proc Nutr Soc, 73(1), 34-46.

Pripp, A. H., Isaksson, T., Stepaniak, L., \& Sørhaug, T. (2004). Quantitative structureactivity relationship modelling of ACE-inhibitory peptides derived from milk proteins. Eur Food Res Technol, 219(6), 579-583.

Rao, S., Sun, J., Liu, Y., Zeng, H., Su, Y., \& Yang, Y. (2012). ACE-inhibitory peptides and antioxidant peptides derived from in vitro digestion hydrolysate of hen egg white lysozyme. Food Chem, 135, 1245-1252.

Rico, E., Toldrá, F., \& Flores, J. (1991). Effect of dry-curing process parameters on pork muscle cathepsin $\mathrm{B}, \mathrm{H}$ and L activity. Z Lebensm Unters Forsch, 193(6), 541-544.

Ruiz, J., Ventanas, J., Cava, R., Timón, M. L., \& García, C. (1998). Sensory characteristics of Iberian ham: influence of processing time and slice location. Food Res Int, 31(1), 53-58

Sánchez-Rivera, L., Martínez-Maqueda, D., Cruz-Huerta, E., Miralles, B., \& Recio, I. (2014). Peptidomics for discovery, bioavailability and monitoring of dairy bioactive peptides. Food Res Int, 63, 170-181.

Sebald, K., Dunkel, A., Schäfer, J., Hinrichs, J., \& Hofmann, T. (2018). Sensoproteomics: a new approach for the identification of taste-active peptides in fermented foods. J Agric Food Chem, 66(42), 11092-11104.

Segura-Campos, M., Chel-Guerrero, L., Betancur-Ancona, D., \& HernandezEscalante, V. M. (2011). Bioavailability of bioactive peptides. Food Rev Int, 27(3), 213-226.

Sentandreu, M., \& Toldrá, F. (2001c). Dipeptidyl peptidase activities along the processing of serrano dry-cured ham. Eur Food Res Technol, 213(2), 83-87.

Sentandreu, M. A., Stoeva, S., Aristoy, M. A., Laib, K., Voelter, W., \& Toldrá, F. (2003). Identification of small peptides generated in Spanish dry-cured ham. J Food Sci, 68(1), 64-69.

Sentandreu, M. A., \& Toldrá, F. (1998). Biochemical properties of dipeptidyl peptidase III purified from porcine skeletal muscle. J Agric Food Chem, 46(10), 3977-3984.

Sentandreu, M. A., \& Toldrá, F. (2000). Purification and biochemical properties of dipeptidyl peptidase I from porcine skeletal muscle. J Agric Food Chem, 48(10), 5014-5022.

Sentandreu, M. A., \& Toldrá, F. (2001a). Partial purification and characterisation of dipeptidyl peptidase II from porcine skeletal muscle. Meat Sci, 57(1), 93-103.

Sentandreu, M. A., \& Toldrá, F. (2001b). Dipeptidyl peptidase IV from porcine skeletal muscle: purification and biochemical properties. Food Chem, 75(2), 159-168.

Sentandreu, M. A., \& Toldrá, F. (2007). Evaluation of ACE inhibitory activity of dipeptides generated by the action of porcine muscle dipeptidyl peptidases. Food Chem, 102(2), 511-515. 
Sforza, S., Galaverna, G., Schivazappa, C., Marchelli, R., Dossena, A., \& Virgili, R. (2006). Effect of extended aging of Parma dry-cured ham on the content of oligopeptides and free amino acids. J Agric Food Chem, 54(25), 9422-9429.

Sforza, S., Pigazzani, A., Motti, M., Porta, C., Virgili, R., Galaverna, G., Dossena, A., \& Marchelli, R. (2001). Oligopeptides and free amino acids in Parma hams of known cathepsin B activity. Food Chem, 75(3), 267-273.

Soresi Bordini, C., Virgili, R., Degni, M., Schivazappa, C., \& Gabba, L. (2004). Effect of ageing time on the analytical and sensory parameters of Parma ham. Industria Conserve, 74, 149-160.

Stressler, T., Eisele, T., \& Fischer, L. (2013). Simultaneous monitoring of twelve angiotensin I converting enzyme inhibitory peptides during enzymatic $\beta$ casein hydrolysis using Lactobacillus peptidases. Int Dairy J, 30(2), 96-102.

Tian, M., Fang, B., Jiang, L., Guo, H., Cui, J., \& Ren, F. (2015). Structure-activity relationship of a series of antioxidant tripeptides derived from $\beta$ Lactoglobulin using QSAR modeling. Dairy Sci Technol, 95(4), 451-463.

Toldrá, F. (1998). Proteolysis and lipolysis in flavour development of dry-cured meat products. Meat Sci, 49, S101-S110.

Toldrá, F., Aristoy, M. C.., \& Flores, M. (2000). Contribution of muscle aminopeptidases to flavor development in dry-cured ham. Food Res Int, 33, 181-185.

Toldrá, F., Cerveró, M. C., \& Part, C. (1993). Porcine aminopeptidase activity as affected by curing agents. J Food Sci, 58(4), 724-726.

Toldrá, F., \& Flores, M. (1998). The role of muscle proteases and lipases in flavor development during the processing of dry-cured ham. Crit Rev Food Sci Nutr, 38(4), 331-352.

Tomkinson, B. (1999). Tripeptidyl peptidases: enzymes that count. Trends Biochem Sci, 24(9), 355-359.

Udenigwe, C. C. (2014). Bioinformatics approaches, prospects and challenges of food bioactive peptide research. Trends Food Sci Technol, 36(2), 137-143.

Udenigwe, C. C., \& Aluko, R. E. (2012). Food protein-derived bioactive peptides: production, processing, and potential health benefits. J Food Sci, 77(1), R11-R24.

Udenigwe, C. C., \& Fogliano, V. (2017). Food matrix interaction and bioavailability of bioactive peptides: two faces of the same coin? J Funct Foods, 35, 9-12.

van Platerink, C. J., Janssen, H. G. M., \& Haverkamp, J. (2008). Application of at-line two-dimensional liquid chromatography-mass spectrometry for identification of small hydrophilic angiotensin l-inhibiting peptides in milk hydrolysates. Anal Bioanal Chem, 391(1), 299-307.

Wu, J., \& Aluko, R. E. (2007). Quantitative structure-activity relationship study of bitter di- and tri-peptides including relationship with angiotensin Iconverting enzyme inhibitory activity. J Pept Sci, 13(1), 63-69.

Wu, J., Aluko, R. E., \& Nakai, S. (2006). Structural requirements of angiotensin Iconverting enzyme inhibitory peptides: quantitative structure-activity relationship study of di-and tripeptides. J Agric Food Chem, 54(3), 732-738.

Wu, J., Liao, W., \& Udenigwe, C. C. (2017). Revisiting the mechanisms of ACE inhibitory peptides from food proteins. Trends Food Sci Technol, 69, 214-219.

Zamyatnin, A. A., Borchikov, A. S., Vladimirov, M. G., \& Voronina, O. L. (2006). The EROP-Moscow oligopeptide database. Nucleic Acids Res, 34, D261-D266.

Zhao, G. M., Zhou, G. H., Xu, X. L., Peng, Z. Q., Huan, Y. J., Jing, Z. M., \& Chen, M. W. (2005). Studies on time-related changes of dipeptidyl peptidase during processing of Jinhua ham using response surface methodology. Meat Sci, 69(1), 165-174

Zheng, L., Zhao, Y., Dong, H., Su, G., \& Zhao, M. (2016). Structure-activity relationship of antioxidant dipeptides: dominant role of Tyr, Trp, Cys and met residues. J Funct Foods, 21, 485-496.

Zhu, C. Z., Tian, W., Li, M. Y., Liu, Y. X., \& Zhao, G. M. (2017). Separation and identification of peptides from dry-cured Jinhua ham. Int J Food Prop, 20(S3), S2980-S2989.

Zhu, C. Z., Zhang, W. G., Zhou, G. H., Xu, X. L., Kang, Z. L., \& Yin, Y. (2013). Isolation and identification of antioxidant peptides from Jinhua ham. J Agric Food Chem, 61(6), 1265-1271.

\section{Publisher's Note}

Springer Nature remains neutral with regard to jurisdictional claims in published maps and institutional affiliations. 